\title{
THE SUPREME COURT OF CANADA AND THE “FAIR DEALING TRILOGY": ELABORATING A DOCTRINE OF USER RIGHTS UNDER CANADIAN COPYRIGHT LAW
}

\author{
MYRA J. TAWFIK*
}

\section{INTRODUCTION}

\begin{abstract}
Canadian intellectual property law as a whole has been shaped by general considerations that are characteristic of this nation. If, on the one hand, the internationalisation of foreign influences has been an inevitable component of the process ... this exercise has not prevented it from finding room for home-grown approaches.... The result is an almost surprising affirmation of individuality. ${ }^{1}$
\end{abstract}

On 12 July 2012, the Supreme Court of Canada rendered five copyright decisions simultaneously. ${ }^{2}$ This was an astonishing development in Canadian copyright jurisprudential history, especially when one considers that throughout the twentieth century, the Supreme Court of Canada averaged only one decision every three or so years. ${ }^{3}$ It is not surprising, then, that these decisions have elicited considerable interest and scholarly attention. ${ }^{4}$

There is no doubt that copyright issues have consumed the docket in a way previously unheard of. Although one can ascribe a number of factors to this phenomenon, two circumstances in particular have contributed to this increased scrutiny by Canada's highest appellate court. Firstly, with the advent of the internet, traditional conceptions of copyright have had to be re-imagined. The digital age has so transformed the way in which creators, industry, and users engage with copyright works that legislatures and courts must calibrate and recalibrate the law to meet the particular demands of this new and revolutionary technology. In light of this, it is not surprising that three of the five cases in the pentalogy address digital copyright concerns with the Supreme Court of Canada advancing the concept

Professor, Faculty of Law, University of Windsor.

Ysolde Gendreau, "Surfacing: The Canadian Intellectual Property Identity” in Ysolde Gendreau, ed, An Emerging Intellectual Property Paradigm: Perspectives from Canada (Cheltenham: Edward Elgar, 2008) 295 at 296.

2 This pentalogy consists of: Entertainment Software Association v Society of Composers, Authors and Music Publishers of Canada, 2012 SCC 34, [2012] 2 SCR 231 [Entertainment Software]; Rogers Communications Inc v Society of Composers, Authors and Music Publishers of Canada, 2012 SCC 35, [2012] 2 SCR 283 [Rogers]; Society of Composers, Authors and Music Publishers of Canada $v$ Bell Canada, 2012 SCC 36, [2012] 2 SCR 326 [SOCAN]; Alberta (Education) v Canadian Copyright Licensing Agency (Access Copyright), 2012 SCC 37, [2012] 2 SCR 345 [CCLA]; Re: Sound v Motion Picture Theatre Associations of Canada, 2012 SCC 38, [2012] 2 SCR 376 [Re: Sound].

3 An unscientific search on CanLII.org elicited roughly 28 results but regardless of the precise number, it is clear that the Supreme Court of Canada agreed to hear only a handful of copyright cases in an entire 100 year span. In the first dozen years of this century, the Supreme Court of Canada has already rendered a number of significant copyright decisions. In addition to the pentalogy, these key decisions are Théberge v Galerie d'Art du Petit Champlain Inc, 2002 SCC 34, [2002] 2 SCR 336 [Théberge]; CCH Canadian Ltd v Law Society of Upper Canada, 2004 SCC 13, [2004] 1 SCR 339 [CCH]; Society of Composers, Authors and Music Publishers of Canada $v$ Canadian Assn of Internet Providers, [2007] 3 SCR 20; Robertson v Thomson Corp, 2006 SCC 43, [2006] 2 SCR 363 [Robertson]; Euro-Excellence Inc v Kraft Canada Inc, 2007 SCC 37, [2007] 3 SCR 20.

4 Most notably, the recent collection of essays in Michael Geist, ed, The Copyright Pentalogy: How the Supreme Court of Canada Shook the Foundations of Canadian Copyright Law (Ottawa: University of Ottawa Press, 2013) [Geist, Copyright Pentalogy]. 
of " technology neutrality" as the governing interpretive principle through which to approach internet-related claims. ${ }^{5}$

The other significant factor that has led to greater judicial oversight relates to the international pressure to strengthen copyright rights and to limit permitted uses and exceptions. ${ }^{6}$ Resistance to this pressure has resulted in increased recognition of the law's other foundational policy pillar, namely, the public interest in access to copyright works. ${ }^{7}$

This comment will highlight the instrumental role that the Supreme Court of Canada has played in advancing this particular public interest concern by reflecting on the trilogy of cases in which it has developed a distinctly Canadian doctrine of user rights with fair dealing as its core manifestation. More specifically, it will review the two pentalogy cases decided on the basis of fair dealing, namely, $S O C A N^{8}$ and $C C L A,{ }^{9}$ which draw their interpretive strength from the earlier landmark decision of the Court in $\mathrm{CCH} .{ }^{10}$ Building upon $\mathrm{CCH}$, the SOCAN and CCLA decisions establish the parameters of a Canadian approach to fair dealing and provide further depth to the concept of user rights. They achieve this by adopting an introspective and self-referential interpretive process, defining a two-step analysis for fair dealing and reaffirming the educative function of copyright.

\section{AN INTROSPECTIVE AND SELF-REFERENTIAL APPROACH TO STATUTORY INTERPRETATION}

The interpretive analysis employed by the Supreme Court of Canada in the fair dealing trilogy, especially in SOCAN and CCLA, can be characterized as decidedly introspective. The court adopted a very different reasoning process from the expansive transjudicial method that it had been espousing in earlier intellectual property law decisions most notably, Harvard

See in this regard the decisions in Entertainment Software, Rogers and SOCAN (supra note 2), building upon the earlier decision in Robertson (supra note 3). On this aspect of the pentalogy, see Carys Craig, “Technology Neutrality: (Pre)Serving the Purposes of Copyright Law”; Gregory R Hagen, “Technology Neutrality in Canadian Copyright Law,” Chapters 9 and 10 respectively in Geist, Copyright Pentalogy (ibid). See also Cameron Hutchison, "The 2012 Supreme Court Copyright Decisions \& Technology Neutrality,” online: SSRN < http://papers.ssrn.com/sol3/papers.cfm?abstract id $=2157646>$.

$6 \quad$ On copyright expansionism see generally Myra J Tawfik "International Copyright Law and 'Fair Dealing' as a 'User Right,”’ UNESDOC Database online: <http://unesdoc.unesco.org/images/0014/ 001400/140025e.pdf $>$. A recent example of this position can be found in the statement of United States Copyright Register who is reported to have remarked that: "It is my strong view that exceptions and limitations are just that-they are important but they must be applied narrowly.... Copyright is for the author first and the nation second” (Judith Saffer, “An Interview with Register of Copyrights Maria A. Pallante" (2012) 4:4 Landslide 10 at 13).

7 Perhaps the strongest reflection of this "push back" at the international level can be found in the "Access to Knowledge” movement that has united consumer activist organizations, civil society, and social justice advocates in the common goal of advancing the public interest in access to knowledge. See Lea Shaver, ed, Access to Knowledge in Brazil: New Research on Intellectual Property, Innovation and Development (London: Bloomsbury Academic, 2010); Myra J Tawfik, "International Copyright Law, Access to Knowledge and Social Justice” in S Ilcan, ed, Mobilities, Knowledge and Social Justice (Montreal: McGill-Queen's University Press, 2013). The influence of this movement has also been felt at the domestic level, see e.g. Susan K Sell, “Revenge of the 'Nerds': Collective Action against Intellectual Property Maximalism in the Global Information Age” (2013) 15:1 International Studies Review 67. 
College v. Canada (Commissioner of Patents) ${ }^{11}$ and Théberge. ${ }^{12}$ In Théberge, Justice Binnie expressed this broad method of legislative interpretation in this way:

Canada has adhered to the Berne Convention ... and other international treaties.... In light of the globalization of the so-called "cultural industries", it is desirable, within the limits permitted by our own legislation, to harmonize our interpretation of copyright protection with other like-minded jurisdictions. ${ }^{13}$

In other words, Canadian courts were being directed to ensure that, where possible, their interpretation of the Copyright $A c t^{14}$ was consistent with that of "like-minded jurisdictions." In contrast, in the pentalogy as a whole, the court appears to retrench from its expansive approach towards a more conservative interpretive model. ${ }^{15}$

Nowhere is this more guarded statutory analysis more evident than in the fair dealing cases. The approach in SOCAN and CCLA is domestic in scope, drawing on purposive statutory construction, prior Supreme Court of Canada precedents, and Canadian legal scholarship. There was no discussion at all about harmonizing interpretations of fair dealing with other like-minded jurisdictions. In fact, the court specifically rejected the persuasiveness of foreign decisions in its assessment of the fair dealing provisions under the Act.

In SOCAN, the Court reminded us that it had

previously cautioned against the automatic portability of American copyright concepts into the Canadian arena, given the "fundamental differences" in the respective legislative schemes.... This caution has resonance in the fair dealing context. ${ }^{16}$

The Supreme Court of Canada expressly distanced fair dealing from the more open-ended American concept of fair use by stressing the very different statutory texts that would inevitably lead to divergent interpretive analyses:

Unlike the American approach of proceeding straight to the fairness assessment, we do not engage in the fairness analysis in Canada until we are satisfied that the dealing is for one of the allowable purposes enumerated in the Copyright Act. ${ }^{17}$

The Court's statements are of more than passing significance. After the decision in $\mathrm{CCH}$, there had been some discussion about whether Canada had in fact adopted an American-style

2002 SCC 76, [2004] 4 SCR 45 [Harvard Mouse].

Supra note 3.

Théberge, supra note 3 at para 6. See Myra J Tawfik "No Longer Living in Splendid Isolation: The Globalization of National Courts and the Internationalization of Intellectual Property Law” (2007) 32:2 Queen's LJ 573.

RSC 1985, c C-42.

However, the Court does not entirely eschew the need to interpret legislation in a manner consistent with international obligations. In Re: Sound (supra note 2 at para 51), for example, the Supreme Court of Canada affirmed that courts must interpret domestic legislation in a manner "consonant with the relevant international obligations.”

SOCAN, supra note 2 at para 25.

Ibid at para 26. For a comparative analysis of the differing approaches see Sarah Sklar-Heyn "Battling Clearance Culture Shock: Comparing U.S. Fair Use and Canadian Fair Dealing in Advancing Freedom of Expression in Non-Fiction Film” (2011) 20:1 Cardozo J Int'l \& Comp L 233. 
"fair use" model. ${ }^{18}$ In its assertion about the inapplicability of American concepts, the Supreme Court of Canada is clearly and unequivocally charting its own course and defining its own interpretive process even though, arguably, expansive fair dealing principles had already been mapped out in history. ${ }^{19}$

More striking still is the Court's explicit rejection of precedents from the United Kingdom and other Commonwealth jurisdictions. In CCLA, the Court did not find the British and New Zealand decisions cited by the defendant to be "particularly helpful." ${ }^{20}$ In distinguishing them on their facts, the Supreme Court of Canada expressed the view that the UK has tended "to take a more restrictive approach to determining the 'purpose' of the dealing than does CCH." ${ }^{21}$ Even though the drafting of the fair dealing provisions under our Act derives its provenance from the British statutory text, ${ }^{22}$ the UK and, presumably, similarly "likeminded" Commonwealth sources no longer offer any relevant interpretive models from which to draw, at least insofar as fair dealing is concerned. The law of fair dealing is to be assessed and judged on the strength of Canadian legal principles alone.

With this introspective and self-referential reasoning process, the Supreme Court of Canada is staking its claim to an interpretive space distinct from its American and Commonwealth counterparts. This is a very different court from the one in Théberge or Harvard Mouse that had expressly measured its decisions in light of other jurisdictional comparators. This forceful assertion of a Canadian copyright identity demonstrates a depth of understanding of, and a confidence in, Canada's own particular copyright story. ${ }^{23}$ There is no need for transjudicial interpretive wanderings. Canadian copyright law is sufficiently well developed and internally coherent to stand on its own merits.

See e.g. Barry Sookman \& Dan Glover, "More Fickle than Fair: Why Canada Should Not Adopt a Fair Use Regime,” online: Barry Sookman <http://www.barrysookman.com/2009/11/22/more-fickle-thanfair-why-Canada-should-not-adopt-a-fair-use-regime/>. See also Giuseppina D’Agostino, "Healing Fair Dealing? A Comparative Copyright Analysis of Canada’s Fair Dealing to U.K. Fair Dealing and U.S. Fair Use” (2008) 53:2 McGill LJ 309; Meera Nair, "Fair Dealing at a Crossroads” in Michael Geist, ed, From "Radical Extremism" to "Balanced Copyright" Canadian Copyright and the Digital Agenda (Toronto: Irwin Law, 2010) 90 [Geist, Canadian Copyright]. Some argue that Canadian law has, in fact, already moved in this direction, see e.g. Michael Geist, "Fairness Found: How Canada Quietly Shifted from Fair Dealing to Fair Use” in Geist, Copyright Pentalogy, supra note 4, 157. This same debate over fair dealing versus fair use has formed the basis of debate and discussion in other Commonwealth jurisdictions, most notably, Australia. See e.g. Austl, Commonwealth, Australian Law Reform Commission, Copyright and the Digital Economy (2001) (Discussion Paper 79), online: Australian Law Reform Commission <http://www.alrc.gov.au/sites/default/files/pdfs/publications/dp79_whole_pdf _.pdf $>$, proposing an open-ended fair use provision to replace the existing fair dealing provision in Australian copyright legislation.

19 Ariel Katz, "Fair Use 2.0: The Rebirth of Fair Dealing in Canada" in Geist, Copyright Pentalogy, supra note 4 at 93.

CCLA, supra note 2 at para 19.

Ibid.

On the British Copyright Act, 1911 (UK), 1 \& 2 Geo 5, c 46, and its influence on Canada, see Ysolde Gendreau "No Copyright Law is an Island" in Uma Suthersanen \& Ysolde Gendreau, eds, A Shifting Empire: 100 Years of the Copyright Act 1911 (London: Edward Elgar, 2013) 226.

23 This expression of individuality is to be lauded. Historically, Canada's copyright laws and policies were too often the result of compulsion or pressure from the outside - the UK during the 19th century and later by the US. On colonial copyright see Sara Bannerman, The Struggle for Canadian Copyright: Imperialism to Internationalism 1842-1971 (Vancouver: UBC Press, 2013); Eli McLaren, Dominion and Agency: Copyright and the Structuring of the Canadian Book Trade 1867-1918 (Toronto: University of Toronto Press, 2011). On the influence of the US on Canadian copyright law and policy see e.g. AA Keyes, “What is Canada’s International Copyright Policy” (1993) 7:3 Intellectual Property Journal 299. 
This judicial assertiveness should not, however, be understood as an expression of Canadian exceptionalism in the area of copyright law. The Supreme Court of Canada is acting within the confines of the international copyright system that itself recognizes the necessity of permitted uses, including fair dealing, to counter-balance possible abuses of the copyright monopoly. ${ }^{24}$

\section{The Crystallization OF A TWo-STeP TeSt for FAIR DeAling}

There is no question that the Supreme Court of Canada has been at the vanguard in interpreting copyright law as a balance between copyright rights and user rights. In the Théberge decision, the Court first reflected on this balancing of interests when it stated that

[t]he Copyright Act is usually presented as a balance between promoting the public interest in the encouragement and dissemination of works of the arts and intellect and obtaining a just reward for the creator.

The proper balance ... lies not only in recognizing the creator's rights but in giving due weight to their limited nature. $^{25}$

However, the Court in Théberge never expressly equated "giving due weight to the limited nature of the rights of creators" with "user rights." It was the later $C C H$ decision that operationalized the principle of balance by introducing the concept of "user rights" within the copyright paradigm. ${ }^{26}$ In this decision, the Supreme Court of Canada also identified fair dealing under the Act as one of the user rights contemplated by law.

The fair dealing exception, like other exceptions in the Copyright Act, is a user's right. In order to maintain the proper balance between the rights of a copyright owner and users' interests, it must not be interpreted restrictively. $^{27}$

The decision in $\mathrm{CCH}$ was a watershed moment in Canadian copyright law. Guidance from our highest appellate court was long overdue. Prior to the $\mathrm{CCH}$ decision, jurisprudential developments in relation to fair dealing had been relegated to judgments at first instance, with courts restrictively construing the scope of the provision with little analysis to support their interpretation other than the assumption that copyright law was primarily designed for creators and industry. ${ }^{28} \mathrm{CCH}$ was the first time in Canadian judicial history that the Supreme

24 See generally, Sam Ricketson \& Jane C Ginsburg, International Copyright and Neighbouring Rights: The Berne Convention and Beyond, 2d ed (Oxford: Oxford University Press, 2005). See also Ruth Okediji, The International Copyright System: Limitations, Exceptions and Public Interest Considerations for Developing Countries (Geneva: International Centre for Trade and Sustainable Development, 2006).

Théberge, supra note 3 at paras 30-31.

26 See Abraham Drassinower, “Taking User Rights Seriously,” in Michael Geist, ed, In the Public Interest: The Future of Canadian Copyright Law (Toronto: Irwin Law, 2005) 462 [Geist, Public Interest]. $\mathrm{CCH}$, supra note 3 at para 48 .

For a thorough examination of the law of fair dealing in Canada and the impact of the $C C H$ decision see e.g. Carys Craig, "The Changing Face of Fair Dealing in Canadian Copyright Law: A Proposal for Legislative Reform,” in Geist, Public Interest, supra note 26, 437. 
Court of Canada specifically addressed the question of fair dealing under the Act, and it did so by characterizing it as a user right. In order to give effect to this user right, the legislated categories of dealings - research or private study, criticism, or review and news reporting — were to be broadly construed. ${ }^{29}$ The Court then outlined a number of non-exhaustive factors upon which to assess the fairness of the dealing in question, namely, the purpose of the dealing, the character and amount of the dealing, whether there were alternatives to the dealing, the nature of the work, and the effect that the dealing had on the work.

The significance of the $\mathrm{CCH}$ decision is borne out by the fact that the most recent amendments to the Act have left the drafting of the fair dealing provision intact. In fact, section 29 has been expanded to include two new categories of "education" and "parody or satire" in addition to the original enumerated ones of "research" and "private study." Parliament had certainly been free to choose to amend the language of the fair dealing provisions to limit the application of $\mathrm{CCH}$ or to abrogate it entirely. The fact that Parliament did not interfere with the ruling in $\mathrm{CCH}$ confirms that it has entrusted the interpretive scope of fair dealing to the courts.

With the decisions in SOCAN and CCLA, rendered while the legislative amendments were pending, the court's overarching role in the interpretation and application of fair dealing has been reinforced. These two judgments must therefore be situated within a continuum that began with $\mathrm{CCH}$ and extended beyond their particular decision-making moment, with the impending statutory changes within their field of vision. As a result, the precedential weight of the entire fair dealing trilogy is significant. These decisions represent the most authoritative expressions of principle in relation to the conceptualization of "user rights" and the specific parameters of fair dealing.

At issue in SOCAN was whether short previews of musical works should be subject to a copyright tariff. In its unanimous decision, the Court determined that the previews constituted fair dealing for the purpose of research. In CCLA, the question was whether it was fair dealing for private study or research for teachers to make copies of short excerpts of copyright works for students in their classes. Although four justices dissented, the majority of the Court upheld the dealing as fair. ${ }^{30}$ Both SOCAN and CCLA expressly endorsed and applied the $C C H$ analysis, including the dissenting justices in the latter decision who, in spite of arriving at a different outcome, nevertheless applied the $\mathrm{CCH}$ factors, finding them "useful for purposes of the fair dealing analysis." ${ }^{31}$

What is of particular importance about the SOCAN decision is that it spoke in terms of a "two-step test" for fair dealing, thereby clarifying and further refining the court's approach to this legislated permitted use. ${ }^{32}$ Under this formulation, the courts must first determine whether the dealing in question falls within a legislated category. Only once this has been established will the court turn to an assessment of the fairness of the dealing in light of the

In $\mathrm{CCH}$, the Court stated that “'Research' must be given a large and liberal interpretation in order to ensure that users' rights are not unduly constrained” (supra note 3 at para 51).

The dissenting opinion was to the effect that the dealing was for public study rather than private study or research (CCLA, supra note 2).

Ibid at para 39.

SOCAN, supra note 2 at para 13. 
$\mathrm{CCH}$ factors. In and of itself, this approach is not novel and was certainly implicit in the reasoning of the Court in $C C H$. However, what the SOCAN decision has done is to strengthen the analytical framework by defining the approach as a legal test and identifying the appropriate threshold for each step of the test as follows: "In mandating a generous interpretation of the fair dealing purposes ... the Court in $\mathrm{CCH}$ created a relatively low threshold for the first step so that the analytical heavy-hitting is done in determining whether the dealing was fair." ${ }^{33}$ The contours of this test had not been as clearly articulated by the Court in $\mathrm{CCH}$.

That the categories are to be broadly construed with the "analytical heavy hitting" consigned to the fairness inquiry provides greater clarity to the nature of the sifting process that lies at the heart of the fair dealing analysis. This systematic method offers a useful roadmap for future determinations of fair dealing especially in cases involving the new statutory categories.

However, no matter how broadly one sets the boundaries of each category, they are nevertheless exhaustive. There will always be factual situations that will fall outside even the most generous interpretation of any given category, in which case the matter will end there. This is not the same approach as that undertaken in the US where a given use is not similarly constrained by statutory categories and where the inquiry revolves entirely around the question of fairness. For example, the act of recording a television broadcast for later viewing, considered a fair use under US law, ${ }^{34}$ is not a dealing that fits neatly within an enumerated category regardless of how generous the interpretation. As a result, Parliament has enacted section 29.23 so as to permit individuals to engage in this type of "time-shifting." Similarly, the "space shifting" of music from one device to another is an activity that cannot be easily justified within any legislated dealing. The Act now contains a specific exception to permit this use under prescribed conditions. ${ }^{35}$ What these examples suggest is that the range of user activities within the confines of fair dealing is not open-ended and limitless.

Further, in terms of the second-step fairness analysis, the Supreme Court of Canada has already provided an indication of what sorts of activities would be considered unfair. For example, in light of CCLA, it would be extremely difficult to justify reproducing books in full for an entire class whether for "research or private study" or for "education." Similarly, the reasoning in SOCAN decision suggests that the act of downloading music previews as opposed to streaming them would be prima facie unfair. There is no question but that as the jurisprudence evolves and becomes more robust, the boundaries between fair and unfair dealings will become clearer. The elaboration of a two-pronged approach that mandates largesse in interpretation at the first instance and gatekeeping at the second is an important advancement in this area of the law. 


\section{THE ELABORATION OF A DOCTRINE OF USER RIGHTS IN CANADIAN COPYRIGHT LAW}

In both SOCAN and CCLA, the Court focused its attention squarely on defining the nature and scope of the concept of "user rights." In SOCAN, the Court identified the Théberge decision as "a move away from an earlier, author-centric view." ${ }^{36}$ It described this earlier decision as having "focused attention ... on the importance copyright plays in promoting the public interest, and emphasized that the dissemination of artistic works is central to developing a robustly cultured and intellectual public domain." ${ }^{37}$ In expressly recognizing this shift away from an "author-centric" view and in asserting that copyright should encourage a "robustly cultured and intellectual public domain," the Supreme Court of Canada has charted its particular vision of the foundational purpose of the law.

Further, the Court in SOCAN characterized the public interest underlying the law as a balance between "protection" and "access," and it described the decision in $C C H$ as confirming that "one of the tools employed to achieve the proper balance between protection and access in the Act is the concept of fair dealing." 38 This too is a new judicial refinement. The Court in $\mathrm{CCH}$ never used the term "access" to describe the user side of the balance; instead it referred only to "ensuring that users' rights are not unduly constrained."39

Speaking in terms of a user's right of access to copyright works is subtle but meaningful. Recognizing the need to encourage the dissemination of works for the benefit of society does not place the focus on the individual user as the locus of legislative attention. Dissemination is the end in itself — the recipients remain invisible and unaccounted for. However, speaking in terms of "access" centres the discussion more squarely on the individual's engagement as a user within the legislative scheme in the sense that access is provided to someone. Framed in terms of balance, what this means is that the rights of the copyright holder to protection must be weighed against the user's right of access. The adoption of the term "access" by the Supreme Court of Canada and the context within which it is discussed reflects an understanding of the "centrality of [access] to the copyright system, and indeed its status as a foundation of democratic culture." ${ }^{40}$ For, as the Court itself recognized, it is through access that a "robustly cultured and intellectual public domain" is fostered and sustained.

Second, the Supreme Court of Canada affirmed that the right of access is not contingent upon the development of new copyright works. A doctrine of user rights should not be premised on whether the use is transformative or leads to new creative works. In SOCAN, the Court recognized that research could be "undertaken for no purpose except personal interest." ${ }^{41}$ Engaging with copyright works for personal edification alone is an important social imperative of which the law must take account. As the Court observed, "dissemination ... with or without creativity, is in the public interest." 42 The user's right of access therefore

SOCAN, supra note 2 at para 9.

Ibid at para 10 .

Ibid at para 11 .

CCH, supra note 3 at para 51.

Laura J Murray, “Copyright Talk: Patterns and Pitfalls in Canadian Policy Discourses,” in Geist, Public Interest, supra note 26, 15 at 39.

SOCAN, supra note 2 at para 22.

Ibid at para 21. 
transcends copyright constructs that define its scope in terms of providing incentives and rewards for creativity. Here again, the Court contrasted its interpretation with the American judicial approach that looks for a transformative purpose before a use can be considered fair. $^{43}$

Finally, the Court recognized the privileged position of the user within the educational setting. If learning for learning's sake is a public interest objective under Canadian copyright law, then learning within the educational context must enjoy a special place within the legal framework.

In the CCLA decision, the Court specifically interpreted the meaning of "research or private study" within the context of a particular educational setting, namely within the elementary and secondary school system. In determining that teachers could make copies of short excerpts of copyright works for their students' private study or research, the majority of the Court made it clear that "[i]nstruction and research/private study are, in the school context, tautological."

Facilitating and encouraging education is a core value within the copyright paradigm. Historically, the law was designed as much around the encouragement of learning as it was about protecting, rewarding, and providing incentives to creators. ${ }^{45} \mathrm{In}$ fact, one could argue that a predominant purpose of the law was to facilitate the acquisition of knowledge given that it was born at a time in history when western societies were attempting to establish systems of universal education. ${ }^{46}$ With this impetus came the need for schoolbooks and other educational materials. Copyright law provided the necessary incentives for schoolbook and other book production in order to foster an educated populace. This imperative was also evident within the international copyright system as the advancement of education was recognized as part of international policy from the inception of the Berne Convention in 1886. ${ }^{47}$ Permitted uses to advance educational and other public interest goals have been acknowledged in all of the various international copyright instruments since then. ${ }^{48}$ Most significantly, the first "user rights" copyright treaty, the 2013 Marrakesh Treaty to Facilitate Access to Published Works for Persons who Are Blind, Visually Impaired, or Otherwise Print Disabled is, in its entirety, a permitted uses treaty. ${ }^{49}$ In its preamble, it echoes the same principle of balance between the rights of copyright-holders and rights of users that the Supreme Court of Canada has been articulating in the context of Canadian law. It also specifically references "education" as one of the public interest imperatives to be safeguarded. The preamble reads, in part:

\footnotetext{
$43 \quad$ Ibid at paras 23-25.

CCLA, supra note 2 at para 23.

See Myra Tawfik, "History in the Balance: Copyright and Access to Knowledge,” in Geist, Canadian Copyright, supra note 18, 69 [Tawfik, "History in the Balance"].

$46 \quad$ Ibid. See also Carla Hesse, "Enlightenment Epistemology and the Laws of Authorship in Revolutionary France, 1777-1793” 30 Representations 109; Mark Rose, "Nine-Tenths of the Law: The English Copyright Debates and the Rhetoric of the Public Domain” (2003) 66:1 Law Contemp Prob 75; Michael J Madison, "Beyond Creativity: Copyright as Knowledge Law” (2010) 12:4 Vanderbilt Journal of Entertainment and Technology Law 817.

47 Tawfik, "History in the Balance," supra note 45.

See e.g. supra note 24.

31 July 2013, WIPO VIP/DC/8, online: World Intellectual Property Organization <www.wipo.int/
} edocs/mdocs/copyright/en/vip_dc/vip_dc_8_rev.pdf>. 
Recognizing the need to maintain a balance between the effective protection of the rights of authors and the larger public interest, particularly education, research and access to information, and that such a balance must facilitate effective and timely access to works for the benefit of persons with visual impairments or with other print disabilities. $^{50}$

Contemporary constructions of copyright must continue to recognize this essential feature of the law. A successful copyright law must continuously mediate between the various and often-competing interests at play — those of creators, industry, and users. An ideal balance should provide incentives for creative production along with opportunities for unconstrained access to advance certain public purposes, including education. The Supreme Court of Canada has certainly made this clear in its CCLA decision by affirming the special place of education in copyright policy.

The importance of this public policy interest has also been confirmed by Parliament in the recent addition of fair dealing for "education" in section 29 of the Act. One could surmise that if the CCLA case came before the court today, the decision would not be divided. Reproducing short excerpts of copyright works for a classroom of students would certainly be considered a dealing for the purpose of "education," regardless of whether the activity in question was for "private" or "public" study. The court would still have to assess the fairness of the dealing. However, this new statutory category has effectively liberated the educative imperative of the law from the textual constraints of "private study" and "research."

\section{CONCLUSION}

In both process and substance, the Supreme Court of Canada has charted a decidedly Canadian approach to surveying the boundary between copyright protection and a "robustly cultured and intellectual public domain.” With $\mathrm{CCH}$ as its starting point and through its decisions in SOCAN and CCLA, the Supreme Court of Canada has enhanced and refined the legal principles relating to fair dealing under Canadian law. It has provided a purposive and purposeful understanding of the core concept of user rights and the appropriate interpretive model for assessing fair dealing. This evolution in the jurisprudence evidences a depth of understanding of the nature of the law and the interests at stake. The fair dealing trilogy is a welcome affirmation of individuality within the larger international and comparative copyright contexts. 